\title{
Critical Issues of Corporate Governance in Chinese Listed Companies-Meet the Standard for a Stable Capital Market
}

\author{
Wan Fei
}

\begin{abstract}
When the Chinese stock market collapses in the summer of 2015, the government took measures and tried to stable the market. These interventions are still arguable whether it threaten the rule of law and market fairness. However, the panic from stock market are rooted in the people's uncertain if they have access to the full information from the listed companies, and eventually, whether the companies are doing properly when they are publicly offering their stocks. The paper questions whether transparency is a principle that accepted by the listed company in China, and what are the problems associated with the corporate governance in the companies. The paper used a methodology of case study and interviews with company directors to point out number of common mistakes, and identify some critical issues on the corporate governance. In conclusion, the paper suggests the Chinese state owned enterprises reform plan needs going further and to be clarified in several crucial aspects. The paper then discuss about how the corporate governance should be improved and a standard in Chinese companies should be met for a stable Chinese capital market.
\end{abstract}

Index Terms-China stock market, corporate governance, company law, state owned enterprises, shareholders.

\section{INTRODUCTION}

Chinese stocks experienced a "roller coaster ride" in the summer of 2015. The Shanghai market has fallen 22 percent over the past four trading sessions, its fastest retreat since daily price move limits were introduced in 1996. The Shanghai Composite Index (SSE Index), reached its peak at 5600 in June 2015 and then fell rapidly to around 3300 in August [1]. The government commenced intervening the stock market from late June 2015 onwards, taking the measures such as banning the listed state owned enterprises (SOE) to sell their shares, raising the guaranteed fund level to enter the index futures trading, and stopping leverage financing for investors. In the same time, the government carried out a "judicial investigation" and until end of August 2015 , there are totally 63 cases have be put on "CSRC investigation list" for the charge of "market manipulation", or "inside trading" [2]. There are totally 38 senior managers from the big banks and financial firms such as Mingshen Bank, CITIC Securities, Mingzhu Securities, Ningbo Zhexi Investment $(\mathrm{Xu}$ Xiang), and most recently, Fosun Holdings(Guo Guangchang) have been "under investigation", or will be "prosecuted". These serious problems have eventually resulted in the step down of the top CSRC officers including CSRC chairman and two other top officers [3].

Manuscript received March 25, 2016; July 12, 2016.

Wan Fei is with Zhaoqing University, Guangdong 526061 China (e-mail: phiwan@linkasialaw.com).
As the market continued to fall in September, the Chinese Securities Regulatory Commission (CSRC) proposed a fusing system to stop the China Securities Index (CSI 300) move over $5 \%$ or $7 \%$. This is parallel to the current $10 \%$ individual price limit system introduced in 1996. Recently, the authority confirmed that the fusing system will formally operate from the January $1^{\text {st }}, 2016$. When the CSI 300 move is over 5\%, the stock trading will be fused for 15 minutes, and when it reaches to $7 \%$, the trading will be closed for the day [4]. It appears that a free market in Chinese stocks is gone but it aims to "avoid a system risk" as explained by the authorities. Critics concerns however about whether it is helpful to the market's health and growing in China [5].

The panic from Chinese stock market are rooted in people's uncertain if they have access to the full information from the listed companies, and eventually, whether the companies are doing properly when they are publicly offering their stocks. At present, the Chinese stock market's total value is estimated as 63 trillion RMB, the second largest in the world market.

To remove the continuing fear about the falling market, the Chinese government published the long anticipated plan called Guidance of CCPC and China State Council on Further Reform of the State Owned Enterprises (the Guidance) [6]. The plan aims to divide the current State Own Assets Administration into a State Funds Management and a State Assets Operation System, and initials a series of programs to better manage the SOE in playing their role in the Chinese socialist economy. The Guidance clarified that it will continually cut down the SOE senior managers' salaries, which are criticized by the public for they have "double" identifications of being "government officers", and appointed to the position as a CEO, or a chair of directors. They receive high salaries and bonuses that could be 10-20 times of that for a normal manager or employee. The Guidance provided a plan to introduce a mix ownership for SOE which allows private investors to buy in some shares but the State may still hold the controlling shares. The Guidance does not provide any details about how the state fund management will work properly with the state assets operation. Also, there is no plan yet to discuss about "privatization of SOE" which is a very sensational word in the current Chinese political atmosphere.

After the publishing of this brand new SOE reform plan, criticism from the public still concerned about if the reform is just a piece of repair, whether it could touch the foundation of SOE which are blamed to cause the unfairness in the Chinese stock market. Currently. This market represents for overall $80 \%$ private stock buyers, while only $20 \%$ are institution investors. Though the government has been trying to control the stable of the market, angers for stock price lost during the dramatic market fall of June 2015 are still widely spread in the 
WeChat circles, blogs, and all sorts of internet media. The Chinese stock buyers are mainly targeting on the misleading reports about the listed companies, their stocks, the problems with the insider trading, and the information disclosure of the listed companies. The problem however, is truly a question whether there is a standard of the corporate governance in the listed companies, particularly those listed SOE.

\section{THE Born OF CHINESE StOCK MARKET AND GOLD RUSH TIME FOR LISTED SOE}

In the late 1980's, shortly before the issuing of the first Chinese company law, China started to spin-off its thousands of SOEs into share limited companies, and then listed these share companies into the two "just beginning" national stock exchanges in Shanghai (SSE) and Shenzhen (SZSE). On October 1992, the China Securities Regulation Commission (CSRC) was established to supervise the stock market, and review its regulations. The CSRC's other responsibility is to approve who will be listed on the stock market, among the long-queued companies who submitted their IPO applications. In the first decade, most approved companies were those middle to large SOEs, only a few well-known privately owned but maybe formerly transferred from state owned companies, could be approved for IPO. Since the year 2000, a number of large central government owned SOEs start to list in the Chinese stock market, after they first listed in overseas markets such as Hong Kong and the USA.

There was an active period that Chinese SOEs spun-off their shares to be listed in the stock market, leaving those not-in-business shares in the state owned assets as a parents company (normally called a group company in China). This is a typical spin-off model for those Chinese SOEs who entered into the Chinese stock market.

This spin-off however, caused a big problems when the group company intervenes the listed company. According to statistics in 2004, the overall 64\% shares in the Chinese stock market are those "original founding shares" which are not traded in the market, among them, $46 \%$ are owned by the SOE group companies. The public trading shares in the market only take up $36 \%$ of the whole market [7]. These "original founding shares" became "controlling shares" which could not be purchased through the market; secondly, company's information such as financial information, their business operation, was not strictly applied by the rule of "information disclosure". As a result, when these SOEs were transferred into public companies, the expected company transparency, and its standard of corporate governance is not complied.

Corporate governance, as defined by OECD, is the system by which corporations are directed and controlled. It should be a process established and used to direct and manage the listed SOE business and affairs of the company with such an objective of balancing: attainment of corporate objectives, alignment of corporate behavior, expectations of society, and accountability to recognized stakeholders.

China first regulated the listed company on its Securities Law 1998. On the "CCPC Decision about some Critical Issues on SOE Reform and Development" published on September 22, 1999, it described that "Corporate governance for legal person is the foundation of a company regulations".
Only in 2002, the CSRC issued "Code of Corporate Governance for Listed Companies in China". Later on in May 2006, CSRC issued "Administration of Initial Public Offerings of Securities and Listing". Apart from these general regulations, the two Chinese domestic stock exchanges in Shanghai and Shenzhen have also issued their individual rules on listing of Stocks, i.e. 'Shanghai Stock Exchanges' Rule of Listing of Stocks", and "Shenzhen Stock Exchanges' Rule of Listing of Stocks". Even though, the situation for corporate governance on the listed companies is far more than expected, these problems are mostly because of the control of the parent company in the listed SOE, and their position in the director board.

The fundamental of modern corporate governance is about the principle of "separation between ownership and the operation"'[8]. However, when a listed company is just a child of the state owned shareholder, the parent company, its business operation is also under that control. In fact, most of the directors, supervisors are appointed or nominated by its parents company, and they become an "insider circle" that controls the listed company. This structure has so much impact on the corporate governance: the major shares are not transferrable, the remuneration of those directors and senior managers are not associated with their performance, and the stock price of the company is not reflected by its value. Without adequate information disclosure about the company, most stock buyers would just gamble that they are the first to buy-in at the lower price and sell-out at the higher price. However, there is "somebody" who is not so blind, many investigated cases found that the insider traders are mostly from the company's "insider circle", or the stock dealers such as securities firms.

\section{The CASE OF SANCHUN: What IS THE PROBLEM WITH CORPORATE GOVERNANCE IN CHINA}

The similar problem on corporate governance happens also in the private sector such as a family company, when it could control the board of directors in a joint venture with a SOE company and gradually swallows the SOE big shares.

Sanchuan is a Chinese family company that started business from a small township in a Sezu minority autonomous county, in the southwest mountain area of Zhejiang Province. Sanchun bought its first small hydropower stations in the Jingning County in 1995 and in 5 years' time, it expanded to five stations with a capacity of $16 \mathrm{MW}$ electricity generation. In 2003, it formed a joint venture company with a state owned company Zhongda, started to acquire hydropower stations in China, and has since run 6 completed stations and 4 developing stations in Yunnan province along Qinghe River and White Water River. In 2005, it introduced a Singapore based private equity investor FEF and became a foreign JV company. In 2006, it signed a contract with International Finance Corporation (IFC), DEG, and Paoparc for a totally 35 million Euro loan, and established a project company Sanchun Limited (SEDC) based in Yunnan. In 2008, Asia Development Bank (ADB) provided a private sector investment on Sanchuan with USD 25 million in equity and USD 58.57 million in loan, and later on a complementary financing of USD 120 million[9], became its equity investor 
with $14.99 \%$ shares. Under the restructure of SEDC, IFC owns $8.845 \%$ shares, Sanchuan owns $33.52 \%$ shares and is a holding company of SEDC.

In early 2011, ADB established a technical assistance team to provide consulting for SEDC, with an objective of "improving corporate governance and enhancing institutional capacity of environmental and social management". During the consulting, we undertook a thorough examination in terms of corporate governance in Sanchuan, interviewed each members of the board. When we asked the chairman of SEDC in a private meeting why he also held the position of general manager of company, he admitted that even though the present vice general manager was selected by him, however, he is still not confidential to place him to the CEO position. He indicated that he could only trust the vice for his loyalty without problems, but could not just leave too much charges for him. To be frankly, he said to us, he looks the company as his "child" and he could not let it down. He said maybe they need another 2 or 3 years to appoint a CEO, but at this stage, he himself will be still the general manager to control the company's operation. We suggested to him that a separate company management with the ownership is primarily important to build a well-run transparent company, and it is actually a good corporate governance standard. In another instance when we interviewed with the candidate CEO, we found that he was only in charge of certain office administrative affairs, and not responsible to the company management, even though his experience and background suggest that he is qualified to take the role of CEO. We discovered later on that, while the company's article of association (AOA) has provisions of independent directors and supervisors, in compliance with the Chinese Company Law, the company has not yet provided a position of an independent director on the board. There is a supervisor elected from the company employees committee, but only working part time with no office for supervisors. It is a question whether he could function properly, and play his role as a supervisor. In SEDC, there is no special fund, nor does a necessary measure for the supervisor to carry on his job. Nevertheless, he is not able to fully access the company information when it is in need.

In 2009, IFC conducted a research on Chinese family business and its corporate governance, with case studies on corporate governance taking from several famous figures such as Lee Kum Kee, Fotile, and Peak [10]. It questioned that when a chairperson holds also the general manager position in the company, the management would generally take majority of the seats in the board of directors and dominates the board. It is difficult or almost impossible to supervise the strong management and correct their wrongdoing. Additionally, a family style business is an "insider circle" that tends to exchange their interests by insider trading, and is reluctant to disclose their company information to the public. In terms of corporate governance, this is similar with the controlling shareholders in the SOE.

\section{SOME CRITICAl ISSUES ABOUT CORPORATE GOVERNANCE IN CHINA}

According to a statistics shown in the period of 2007
2009, there were a totally 107 cases being investigated by CSRC in 2010, 53 penalty decisions and 16 market banning had been made. Penalty amounts 55.07 million (RMB), confiscation totals 47.66 million (RMB) and 8.54 million (HKD) [11].

When we read through many CSRC investigated cases, we found the common problem is deeply associated with the corporate governance in the Chinese listed companies. There are some critical issues that faced by the listed companies, particularly, the SOE companies.

\section{A. Unreasonable Shareholding Structure in Chinese Listed Companies}

The percentage for trading shares on a Chinese listed company is general low, and most SOE shares and legal person (founding shares) are not tradable in the stock market. The SOE founding shareholder (a group company) normally dominate the shares in the listed company, result in a single big shareholder in the company's structure of shares. The structure of shares is so concentrated that most seats on the board of directors are taken by the biggest shareholder and his interests members. There are very limited seats that represent the interests of the small shareholders, they cannot hence hold their own argument or defend themselves against the big shareholders

\section{B. The Weak Independence of the Directors and Its Close Relationship with the Control Shareholders}

Because of the high concentrated shares, the board is dominated and thus controlled by the big shareholder, the parent company. There is almost no space for the independence of individual directors in the board.

According to the Chinese regulations, such as the CSRC's Guideline of Establishment of Independent Directors System in the Listed Companies, the represent of independent directors is a legal requirement in a share limited company. However, when the controlling shareholder and its associated directors are taking over $50 \%$ seats on the board, you can barely heard the voice from the other directors in the minority group. Nevertheless, the independent directors are mostly recommended by the big shareholder, they could not truly stand for "independent interests". The Company Law requires that any decision from the board could only be made by over a half directors, but this is being used perfectly by the big shareholders when they control more than $50 \%$ seats in the board. The situation become even worse when the factor of Chinese culture of Guanxi, which means a close relationship with the big boss is your advantage over others, so you will be always defeated by those who want to keep the Guanxi with the big boss.

\section{Independent Director Is not Playing the Role}

When an independent director is selected from a celebrity, such as a famous professor, a social activist or a former governmental official, to makeup the company face, and the director only shows occasionally on the board. It is a question if he is able to contribute enough time to seat in the board meeting. It is even a bigger problem if the company only wants him to fill the position that is legally required but not really want him to play his role. Unfortunately we found this is mostly true when many cases disclosed those independent 
directors failed to bring in precaution onto the board when the companies are doing thing wrong.

\section{A System of Evaluation and Appraisal Has not yet Been Established in the Director Board of Listed Companies}

Most companies may provide a schedule to improve the evaluation of directors on their annual report, however, they normally finish with no details about the assessment of the board, and of the individual directors. On the other side, an incentive rumination of directors is also absent. It is therefore questionable whether the directors really care about the long-term interests of the company? While most directors on listed SOE could not expect a bonus such as share-options through manager buying-out (MBO), they would simply use their position benefits such as travelling allowance, entertainment, and even bribe-taking. There are hundreds of corruption cases each year that have been investigated by CCPC Discipline Inspection Commission (DIC), and brought to prosecution.

\section{E. Insider Trading between the Group Company and the Listed Company}

An insider trading between a listed company and its state-owned parent company or group company involves those conducts such loan on security, manager cash lending, and connected transaction. The damage to the listed company would further threaten the fairness of the market. However, both the first Company Law (1993), or the Securities Law (1996) had not provided any measures to prevent insider trading, until later in 1997, when the Minister of Finance issued its administrative amendment on Company Accounting Regulations: Disclosure of the Interested Parties and their Trading, and CSRC Guidance of Listed Company Articles of Corporation, Opinions on Model Listed Company Shareholders Meeting. Even though, a listed company may not bother to sue their parent company for damage because of the "big shareholder" and its "insider circle" control on the board. On a few cases when the issues were brought into the media and public attention, they are forced to pay off loan owned to the listed company under the interventions of the related governments or CSRC. The case would normally end as the directors, managers resigned from the board, however, the damage would not be brought to a civil procedure for tort in a People's Court. This is why the law is often labeled as "soft law", or "a tiger without teeth" [12].

\section{F. Information Disclosure}

As a public company, full disclosure of company information is a statutory requirement for any listed company. The CSRC has a special provision in its "Administrative Measures on Information Disclosure for Listed Companies" which requires companies to "truly, accurately, completely, and timely disclose information, without any false record, misleading statement, or major omission. The information disclosure should be made public to all the investors". However, this does not stop someone who breaks the rule. Firstly, it is quiet easy for them to delay the disclosure of certain information that is crucial to their stock trading and price. Secondly, the directors or senior managers of the company may purposely make a false report or misleading statements about their company's current financial and business information, their M \& A deal and so on. Lastly, a company may leak certain financial information such as company performance to the institution investors for attracting them to buy. In other cases, management from a listed company can select what information to disclose, such as information about the company assets, sales, and market change so that making it possible for stock manipulation by those inside traders from their company. These inside traders are called 老鼠仓 (Rat-trading) in Chinese.

\section{THE CURRENT SOE REFORM PLAN AND THE FURTHER STEPS}

The standard of corporate governance are provided by several Chinese regulations such Company Law (2005), and the Chinese Code of Corporate Governance on Listed Companies (Code, 2002). However, the Code is a volunteer requirement for general companies. To a listed Chinese company or a company to be listed, they must fully comply with the Code, together with several national regulations for corporate governance standard.

Even though, the compliance with the Code is still a bigger question for those listed Chinese companies, particularly when the enforcement is not on the position. Controlling shareholder encroaches on the listed company' mainly through forcing the listed company to provide guarantee of mortgage loan for related party, or directly seize the circulating fund of the listed company. From a statistics of Shenzhen Stock Exchange (SZSE) on December 31, 2005, the illegal mortgage involved totally 31.58 billion of 118 companies listed in SZSE, counting about $5.96 \%$ of the total net assets of the market value [13].

In the past, a controlling shareholder may directly borrow from a listed company, or force the listed company to engage a delegating loan from banks. They may also let the company to accept a bill of exchange without any commercial transactions, and pay for its debts, employee wages, benefits, insurance and other costs. In recent years, as the controlling shareholder encroaches have been warned by the Stock Exchanges to be "delisting", "trading halt", or "notice of denounce", and in several cases by the CSRC's "administrative penalty", or "notice of rectification and reform in a limited time", they changed to indirect, and more complicated ways such as false information disclosure, manipulating market [14]. They collectively work with their interested partners such as accounting firms, law firms, and asset appraisers to provide false information on financial and audit reports, asset appraising and legal opinions, bank deposit mortgages, and illegal guarantee. They also work together with some stock brokers, private funds to manipulate stock prices by distributing false information in the media about the company's restructuring, profitable business activities, or additional stock issue, unitary IPO, new assets participating, etc. In doing these, they may use a number of anonymous accounts, "shell companies", so there were only a few big shareholders that had been caught by CSRC. According to a statics showed in period of $2007-2009$, the shareholders subjected to penalties ware only taking $2.9 \%$ 
among other subject catalogues such as listed company and senior managers $(63.41 \%)$, securities companies (12.32), and intermediary firms $(8.70 \%)$. There were a total of 107 cases being investigated by CSRC in 2010, 53 Penalty Decisions and 16 Market Banning had been made [15].

This is mostly because of the missing statutory liabilities to those controlling shareholders who hold their hidden position in the board of a listed company. Furthermore, the evidential burden for any possible shareholders to sue their controlling holders for a civil liability in the Court is a very difficult one. Section 152 of the Company Law provided a shareholder of a listed company could launch a derivative action against the controlling shareholder through supervisor or its commission, however it is not practicable, considering the big boss controlling the board. It is therefore expected that the Chinese regulators need to amend the Securities Law particularly its monitoring measures to crack down the offensive behaviors of those controlling holders. Technically, it will be only practicable if placing the big shareholder more burden of proof when information disclosure is the case. It is suggested that, any future amendment to the Sect. 69 of Securities Law needs to include details about controlling shareholders responsibilities to its subsidiary listed company such as the regulation of presumed-fault applies to their civil liability in the case of shareholders derivative suit [16].

In fact, most CSRC invested cases ended up with an administrative penalty, and the offender being sentenced into prison. There is no judicial compensation for individual investors who can bring in a law suit in the People's Court. "Class action" in the Chinese judicial system is still a very sensitive word that is considered by the government to be a cause for society instability. As a result, most these civil compensation cases would be rejected in front of the court filing procedure that are seen to be a judgment without a judger [17].

The newly issued "Guidance of CCPC and China State Council on Further Reform of the State Owned Enterprises <The Guidance> aimed to approve the SOE corporate governance. In the past, a son company was first spun-off in assets from its parent SOE (group) company, and then listed in the market. This caused the major problem of related party transactions. The Guidance suggested, when it is appropriate, the group company will be listed in the stock market so it may cut the related transactions.

To change the situation that SOE taking as the only big shareholder, in certain industries where competition orientated market, the non-SOE or other SOE companies will be allowed to purchase the existing equity of the SOE. This is called "mixed" SOE ownership reform.

As to those natural monopoly industries, the reform of franchise will be taking place, in separating the networks and operations, loosening the competitive area (网运分开、放开 竞争性业务). These networks include certain public utility or services such as national grid, railway and subway system, water supplies, and public transport. Where the SOE is in the position, it will be encouraged to introduce other equity investors from other SOEs. Where franchise is in position, the franchisee can be open to any subjects. This puts those natural monopoly industries in competition, and not to be exclusive from the reform.
The SOE reform will focus on a transfer from business operation to assets management, which means it will let the big shareholder set hands off their subsidiaries, such as the listed companies.

While an administrative structure is a flat pattern, a shareholder management is generally hierarchical model that limited the shareholders power to their direct invested companies. In compliance with the standard of modern company and related laws, a company's business decision is within the power of the company's legal person, who owns the property of the company and has its fully civil liability. As described in the Guidance, the current National State Assets Commission will be working at three levels: State Assets Authority, State Assets Investment and Operation (SAIO), and State Assets in companies (Shareholders). The SAIO will be incorporated as a company which of course will be registered as a legal entity and be fully civil liable. In the level of companies, the state assets is just one of the shareholders of a company. It legally has the equal relation with other shareholders in the company. There will be no more SOE, no more "Big Boss" or Big Shareholder who exceeds its power and control the board of a listed company.

\section{CONCLUSION}

In accordance with the Guidance, SOE will be classified as either a profit or socially interested company, and will be coordinately reformed, developed, monitored, missioned, and appraised. However, the question is, how they could be classified to be profit or non-profit or for social interests? As in the past, many SOEs play in the middle. It appears that administrative measures must be used to settle the issue. It means the game to play in the middle will be over!

SOE assets can be transferred into preferred shares. In the past, some SOEs are those "too big to fall", one may include the whole SOE assets with a value of billions in an industries such as China Agri-Industries (COFCO), China Railway Construction (CRCC), China National Petroleum Corporation (CNPC) and China Petroleum \& Chemical (Sinopec) . In the case of China Huiyuan Juice, the company purchased about $1 \%$ stake of Sinopec Oil Products Company, and it has however little power of discourse on the board. Some people suggested, when SOE is guaranteed a constant return, it may give up the power of operation so that equity investors from the social or private companies could have their voice on the board. This is similar to a "golden share" system - the SOE will hold a state special shares management system, but do not involve the business operation. It looks pretty good but, how is it possible in practice? How does the Central Government proceed with this plan with a goal of "learn from each other in mutual complementarity of different ownership, mutual promotion, and development together (推 动各种所有制资本取长补短、相互促 进 、共同发展)”?

In addition, the remuneration in SOE will be divided in two categories of administration officers and professional managers. While the former can be appointed by the CCPC and the related state assets authority, the later will be only recruited from the public, and paid market salaries. The difficulty is, however, how are the two categories executed in 
one management team of a SOE company, and whether the SOE officers can be selected from a public recruitment to show the equal job opportunity?

In general, this plan of reform SOE aims to solve the core issues of sustainable development in SOE. However, it will need more detail regulations to follow up. The current Code of Corporate Governance was issued on January 2002 and is considered quite out of date. To cope those critical issues on the corporate governance and its association with Chines securities market problem, it is in urgent to update the Code as well as its related laws such as the Company Law and Securities Law [18]. These amendments to regulations will need to set specific rules and measures to monitor the current corporate governance problems. In practice, how to educate the Chinese companies in several aspects such as the principle of transparency and independence of the director's board, is a crucial and first to all step. Only in achieving this, the corporate governance could be improved and a standard in Chinese companies could be met for a stable growing of the capital market in China.

\section{REFERENCES}

[1] Financial Time: Economic nerves return to torment China equities. (Sept. 15, 2015). [Online]. Available: http://www.ftchinese.com/story/001063959/ce

[2] East Money. [Online]. Available: http://stock.eastmoney.com/news/1344,20150901543412132_2.html

[3] Fenghuang Zixun. [Online]. Available: http://news.ifeng.com/a/20160221/47516888_0.shtml

[4] Net [Online]. Ease. Available: http://news.163.com/15/1205/02/BA1PBADR00014Q4P.html

[5] From Jan 4 to Jan.7, 2016, the main board at SSE had been fused for 4 times. On Jan.8, 2016, the fusing system had been officially closed by CSRC. [Online]. Available: http://stock.hexun.com/2016-01-08/181683558.html?from=rss

[6] Xinhua News Agency. The guidance of CCPC and China State Council on further reform of the state owned enterprises. [Online]. Available: http://news.xinhuanet.com/politics/2015-09/13/c_1116547080.htm

[7] China Securities Regulatory Commission. (Sept 15, 2007). [Online]. Available: www.csrc.gov.cn
[8] OECD, Principles of Corporate Governance, OCED Publication Service, 2004.

[9] ADB Project No. 41935-014. [Online]. Available: http://www.adb.org/projects/41935-014/main

[10] IFC Family Business Governance Handbook, 3rd Edition, 2011.

[11] B. Chen, CSRC Securities Administrative Penalty Analysis Report 2010, Securities Market Herald, issue 9, 2011.

[12] See Jiang Xue Yao: Research Report -The Governance of Soft Law on Corporate Governance for Listed Companies, SZSE Research Institute, no. 0183, November 7, 2011.

[13] W. G. Peng, "Perfection of corporate governance of listed companies in China from the perspective of stock exchange," Studies on Corporate Governance, Beijing University Press, p. 240, 2009.

[14] Y. Cai, The New Forms of Big Shareholders Offences, SZSE, issue 8, pp. 33-36, 2010.

[15] B. Chen, CSRC Securities Administrative Penalty Analysis Report 2010, Securities Market Herald, issue 9, 2011.

[16] Y. Cai, The New Forms of Big Shareholders Offences, SZSE, issue 8, p. 36, 2010.

[17] N. P. Liu, Justice without Judges, University of California, Davis, vol. 17, no. 2, p. 284, 2011,

[18] The Chinese State Council, "A draft for comments on the regulation of supervision and administration on listed companies," September 2007.

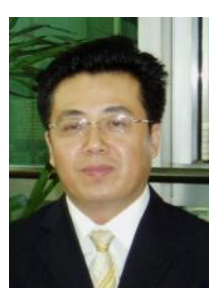

Wan Fei is a Professor of law at Zhaoqing University. Dr. Wan graduated with a $\mathrm{PhD}$ from The University of Melbourne. He is also the Head of China Desk at Linkaisa LLP Attorneys. He served for the World Bank and ADB in China Clean Energy Development Projects from 2011-2012 as the Expert of Corporate Governance and Legal Counsel. He hold lectureship at the MBA Joint Courses for Shanghai Jiatong University and the Sunshine Coast University Australia, and International Business Law for Singapore Informac Institute. He is a frequent speaker at several international conferences including the International Bar Association, Asia Pacific Law Society and SNP's Vista Society of Industrial Leaders. Dr. Wan's education background also include, a LLM from Victoria University of Wellington (New Zealand) and a LLB from Fudan University (Shanghai, China). Dr. Wan's main research areas are: international financial law, international trade law, corporate law and corporate governance, international commercial arbitration and dispute resolutions. 